The Oxford Handbook of QUR'ANIC STUDIES

Offers a definitive collection of studies covering the full spectrum of contemporary international scholarship

associnted with the study of the Qur'an

- An indispensable resource for the academic study of the

Qur'an, mapping milestones in the field

- Provides detailed reviews of key topics and concepts

Contributors

Muhammad Abdel Haleem, Kamal Abu-Deeb, Asma Afsaruddin, Anna Akasoy, Muntasir F. Al-Hamad, Ahmad Al-Jallad, Sulaiman bin Ali bin Ameir Al-Shueili, Herber Berg, Sheila S. Blair Stephen R. Burge, Massimo Campanimi, Michel Cuypers, François Deroche,

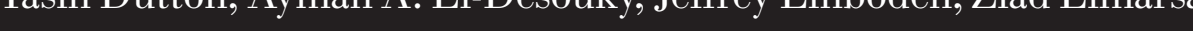
Reuven Firestone, Geert Jan van Gelder, Sebastian Günther, John F. Healey, Valerie J. Hoffman, Tariq Jafier, Jules Janssens, Maher Jarrar, Anthony H. Johns, Maranta Klar, Alexander Knysh, Bruce Lawrence, Oliver Leaman, Joseph E. Lowry, Ulma Martensson,

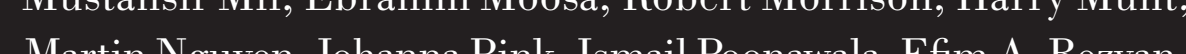

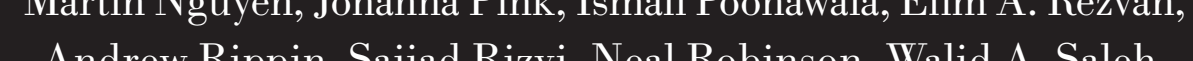
Men Kees Versteegh, Stefan Wild, M. Brett Wilson, A. H. Mathias Zahniser
Shah \&
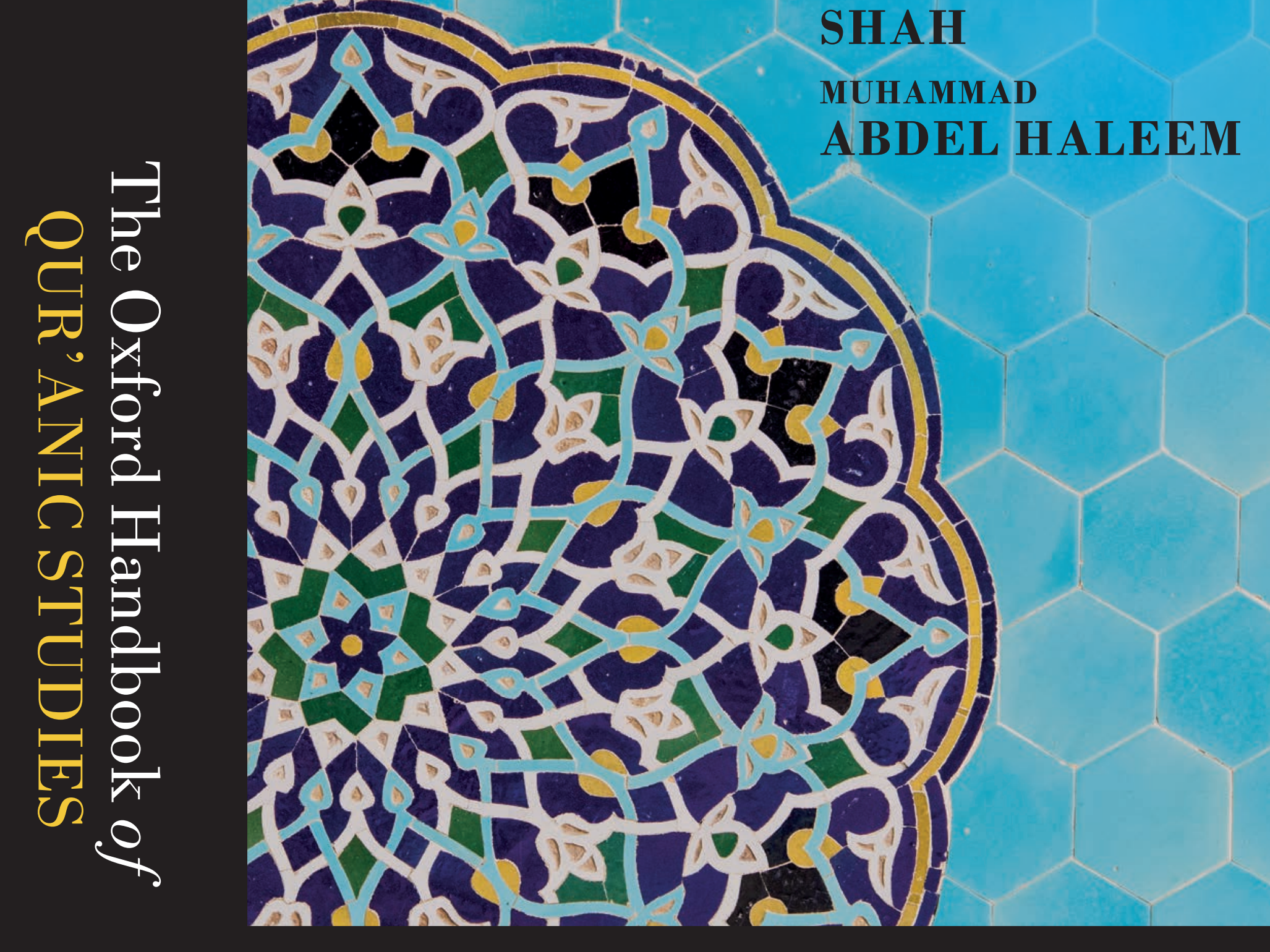

The Oxford Handbook of QUR'ANIC STUDIES 
Shah \&

Abdel Haleem

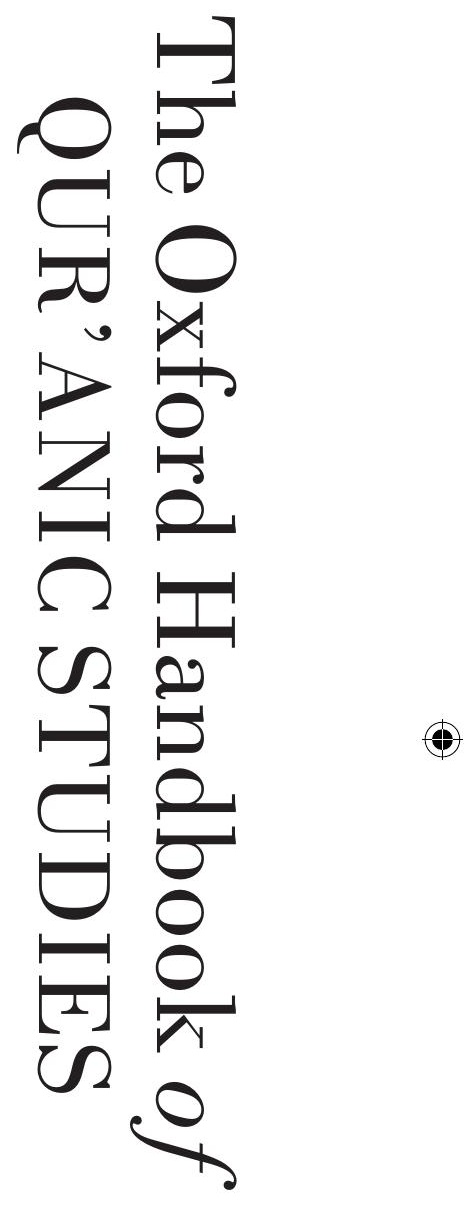

OXFORD 


\section{THE OXFORD HANDBOOK OF}

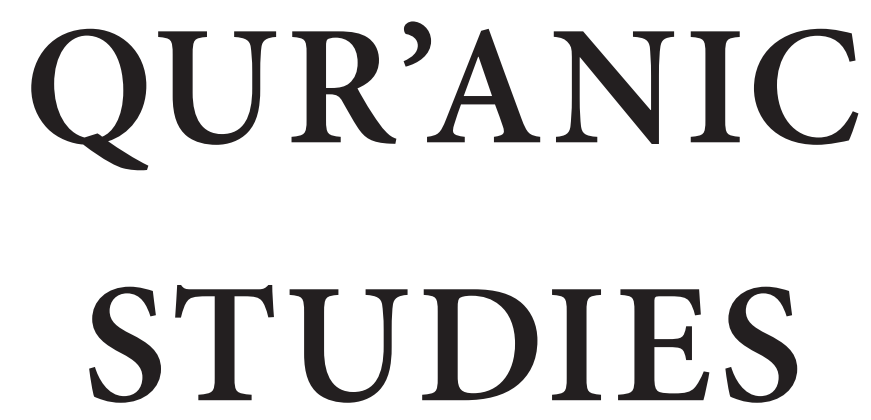

Edited by

MUSTAFA SHAH

and

MUHAMMAD ABDEL HALEEM 


\section{OXFORD UNIVERSITY PRESS}

Great Clarendon Street, Oxford, Ox2 6DP, United Kingdom

Oxford University Press is a department of the University of Oxford. It furthers the University's objective of excellence in research, scholarship, and education by publishing worldwide. Oxford is a registered trade mark of

Oxford University Press in the UK and in certain other countries

(c) Oxford University Press 2020

The moral rights of the authors have been asserted

First Edition published in 2020

Impression: 1

All rights reserved. No part of this publication may be reproduced, stored in a retrieval system, or transmitted, in any form or by any means, without the prior permission in writing of Oxford University Press, or as expressly permitted by law, by licence or under terms agreed with the appropriate reprographics rights organization. Enquiries concerning reproduction outside the scope of the above should be sent to the Rights Department, Oxford University Press, at the address above

You must not circulate this work in any other form and you must impose this same condition on any acquirer

Published in the United States of America by Oxford University Press 198 Madison Avenue, New York, NY 10016, United States of America

$$
\begin{gathered}
\text { British Library Cataloguing in Publication Data } \\
\text { Data available }
\end{gathered}
$$

Library of Congress Control Number: 2019947965

ISBN 978-0-19-969864-6

Printed and bound by

CPI Group (UK) Ltd, Croydon, CRo 4YY

Links to third party websites are provided by Oxford in good faith and for information only. Oxford disclaims any responsibility for the materials contained in any third party website referenced in this work. 


\section{TABle of Contents}

List of Illustrations

xiii

List of Contributors

Introduction

Mustafa Shah

\section{PART I THE STATE OF QUR'ANIC STUDIES}

1. Academic Scholarship and the Qur'an

ANDREW RipPin

2. Modern Developments in Qur'anic Studies

Oliver Leaman

3. Islamic Origins and the Qur'an

Herbert Berg

4. Qur'anic Studies: Bibliographical Survey

Anna Akasoy

\section{PART II THE HISTORICAL SETTING OF THE QUR'AN}

5. Late Antique Near Eastern Context: Some Social

and Religious Aspects

Muntasir F. Al-Hamad and John F. Healey

6. The Arabian Context of the Qur'an: History and the Text HARry MunT

7. The Linguistic Landscape of pre-Islamic Arabia: Context for the Qur'an 
8. Qur'anic Exempla and Late Antique Narratives

Marianna Klar

9. The Qur'an and Judaism

140

Reuven Firestone

10. The Qur'an and Christianity

152

NeAl Robinson

\section{PART III THE QUR'AN: TEXTUAL TRANSMISSION, CODIFICATION, MANUSCRIPTS, INSCRIPTIONS, AND PRINTED EDITIONS}

11. The Manuscript and Archaeological Traditions: Physical Evidence François Déroche

12. The Form of the Qur'an: Historical Contours YAsin Dutton

13. The Corpus of Qur'anic Readings (qirā'āt): History, Synthesis, and Authentication

Mustafa Shah

14. Glorifying God's Word: Manuscripts of the Qur'an SheIla S. Blair

15. Inscribing God's Word: Qur'anic Texts on Architecture, Objects, and Other Solid Supports

Sheila S. Blair

16. A History of Printed Editions of the Qur'an

Efim A. Rezvan

\section{PART IV STRUCTURAL AND LITERARY DIMENSIONS OF THE QUR'AN}

17. Language of the Qur'an 
19. Qur'anic Syntax

Michel Cuy pers

20. Rhetorical Devices and Stylistic Features of Qur'anic Grammar Muhammad Abdel Haleem

21. Inner-Qur'anic Chronology 346 Nicolai Sinai

22. The Structure of the Qur'an: The Inner Dynamic of the Sura 362 Mustansir Mir

23. Discussions of Qur'anic Inimitability: The Theological Nexus 374 Ayman A. El-Desouky

24. The Qur'an and the Arabic Medieval Literary Tradition 388 Geert Jan van Gelder

25. The Qur'an and Arabic Poetry 401 Stefan SperL

\section{PART V TOPICS AND THEMES OF THE QUR'AN}

26. Revelation and Prophecy in the Qur'an 419 Ulrika MÅTENSSON

27. Doctrine and Dogma in the Qur'an 430 STEPHEN R. Burge

28. Law and the Qur'an 445 JosepH E. LOWRY

29. Qur'anic Ethics 464 EBRAHIM Moosa

30. Eschatology and the Qur'an 472 Sebastian Günther

31. Prophets and Personalities of the Qur'an 488 Anthony H. Johns

32. Politics and the Qur'an Stefan Wild 
33. Jihad and the Qur'an: Classical and Modern Interpretations Asma Afsaruddin

34. Women and the Qur'an 527 Asma Afsaruddin

\section{PART VI THE QUR'AN IN CONTEXT: TRANSLATION AND CULTURE}

35. Translations of the Qur'an: Western Languages

Ziad Elmarsafy

36. Translations of the Qur'an: Islamicate Languages

M. BREtT Wilson

37. Presenting the Qur'an Out of Context

Muhammad Abdel Haleem

38. Popular Culture and the Qur'an: Classical and Modern Contexts

Bruce LaWrence

39. The Western Literary Tradition and the Qur'an: An Overview JefFrey EINBoden

\section{PART VII QUR'ANIC INTERPRETATION: SCHOLARSHIP AND LITERATURE OF EARLY, CLASSICAL, AND MODERN EXEGESIS}

40. Early Qur'anic Commentaries

ANDREW Rippin

41. Exegetical Designs of the Sìra: Tafsìr and Sìra Maher Jarrar

42. Early Qur'anic Exegesis: From Textual Interpretation to Linguistic Analysis

KeEs Versteegh

43. Early Medieval Tafsìr (Third/Ninth to the Fifth/Eleventh Century) 
44. Medieval Exegesis: The Golden Age of Tafsìr 666 Walid A. Saleh

45. The Corpora of Isrä'ìliyyāt 682 Roberto Tottoli

46. Contemporary Tafsìr: The Rise of Scriptural Theology 693 WALID A. SAlEH

\section{PART VIII QUR'ANIC EXEGESIS: DISCOURSES, FORMATS, AND HERMENEUTICS}

47. Twelver Shī̄̄ì Exegesis

SAJJAD Rizvi

48. Ismāèilì Scholarship on Tafsīr

721

IsMail PoONAWALA

49. Ibāḍi Tafsīr Literature

Valerie J. Hoffman and Sulaiman bin Ali bin Ameir Al-Shueili

50. Sufi Commentary: Formative and Later Periods

746

Alexander Knysh

51. Theological Commentaries

766

TARIQ JAFFER

52. Philosophical Commentaries

780

Jules JANSSENS

53. Aesthetically Oriented Interpretations of the Qur'an

794

Kamal Abu-Deeb

54. Tafsìr and Science

806

ROBERT MORRISON

55. Classical Qur'anic Hermeneutics

818

Johanna Pink

56. Sunnī Hermeneutical Literature

832

Martin Nguyen

57. Modern Qur'anic Hermeneutics: Strategies and Development

848 Massimo Campanini 